\title{
АКТУАЛЬНІ ПРОБЛЕМИ ОРГАНІЗАЦІЇ ТА НАДАННЯ МЕДИЧНОЇ ДОПОМОГИ НА КОНТРОЛЬНОМУ ПУНКТІ В’ЇЗДУ-ВИЇЗДУ «СТАНИЦЯ ЛУГАНСЬКА» В ЛУГАНСЬКІЙ ОБЛАСТІ ЗА УМОВ ПРОВЕДЕННЯ АНТИТЕРОРИСТИЧНОЇ ОПЕРАЦІї - ОПЕРАЦІї ОБ'ЄДНАНИХ СИЛ
}

\author{
Н. М. Стешенко ${ }^{1}$, О. Н. Литвинова ${ }^{2}$ \\ ${ }^{1}$ Комунальне некомериійне підприємство Луганської обласної ради \\ "Луганська обласна клінічна лікарня" \\ ${ }^{2}$ Тернопільський національний медичний університет \\ імені І. Я. Горбачевського МОз України
}

\begin{abstract}
У статті висвітлено проблеми організації та надання медичної допомоги на контрольному пункті в’їздувиїзду «Станиця Луганська» в Луганській області в результаті проведення антитерористичної операції Операції об’єднаних сил. Акцентовано увагу на недостатності та в деяких питаннях відсутності забезпечення доступу цивільного населення до медичної допомоги на контрольному пункті в’їзду-виїзду впродовж лінії розмежування.
\end{abstract}

\section{CURRENT PROBLEMS OF ORGANIZATION AND PROVISION OF MEDICAL CARE AT THE ENTRY-EXIT CHECKPOINT "STANYTSIA-LUHANSKA" IN LUHANSK REGION IN THE CONDITIONS OF ANTI-TERRORISTIC OPERATION - JOINT FORCES OPERATION}

\author{
N. M. Steshenko ${ }^{1}$, O. N. Litvinova ${ }^{2}$ \\ ${ }^{1}$ Municipal non-profit enterprise of Luhansk regional council \\ "Luhansk Regional Clinical Hospital" \\ ${ }^{2}$ I. Horbachevsky Ternopil National Medical University
}

\begin{abstract}
The article highlights the problems of organization and provision of medical care at the entry-exit checkpoint (EECP) "Stanytsia-Luhanska" in Luhansk region as a result of the anti-terroristic operation - joint forces operation. Emphasis is placed on the inadequacies and in some issues the lack of access of the civilian population to medical care at the EECP along the line of demarcation.
\end{abstract}

Вступ. 32014 р. триває збройний конфлікт в Україні. Частину їі території окуповано. Уряд України не має об'єктивної можливості впливати на забезпечення доступу цивільного населення до медичної допомоги в цих регіонах. Лінія розмежування протяжністю в 457 км розділяє підконтрольні та непідконтрольні Уряду України території на сході держави. Відповідно до статті 3 Конституції України, захист життя, здоров'я, честі, гідності, недоторканності та безпеки людини $\epsilon$ найвищою соціальною цінністю. Держава через органи влади зобов'язана забезпечувати їх, щонайменше на підконтрольних уряду територіях. Уздовж лінії розмежування розташовано п'ять контрольних пунктів в'їзу-виїзду (надалі - КПВВ), які є єдиними

(c) Н. М. Стешенко, О. Н. Литвинова, 2020 «вузловими пунктами», що об'єднують території та людей, розділених конфліктом.

Протягом 2018 р. на КПВВ на Сході України карети екстреної медичної допомоги виїздили 559 разів, протягом трьох кварталів 2019 р. - 201 раз. На жаль, не обійшлось і без летальних випадків. У 2018 р. під час перетину лінії розмежування через КПВВ у результаті обстрілів чи загострень проблем зі здоров'ям загинуло понад 50 осіб [1].

Основна частина. Контрольний пункт в'їзду-виїзду розміщений у зоні проведення антитерористичної операції (АТО) і слугує для організації переміщення осіб, транспортних засобів і вантажів через лінію розмежування, в тому числі у зв'язку із станом здоров'я. 
КПВВ $\epsilon$ єдиними пунктами, через які можна легально потрапити з ОРДлО на підконтрольну Україні територію та навпаки. Станом на січень 2020 р. фактично працюють п'ять КПВВ на автомобільних шляхах. Чотири - у Донецькій області: з півночі на південь - «Майорське», «Мар'їнка», «Новотроїцьке», «Гнутове» і єдине КПВВ - у Луганській області: «Станиця Луганська» [2].

Іноді деякі КПВВ тимчасово призупиняють роботу через обстріли бойовиками. Також трапляються випадки викрадення ними людей.

За даними Луганської та Донецької військовоцивільних адміністрацій (ВЦА), більшість людей, які подорожують через КПВВ на Сході України, $\epsilon$ внутрішньо переміщеними особами-пенсіонерами. Вони вимушені перетинати лінію зіткнення заради ідентифікації в Ощадбанку та виконання законодавчих вимог щодо продовження дії довідки внутрішньо переміщених осіб (ВПО), яка $є$ обов'язковою умовою для отримання пенсії (один раз на 59 днів) [3].

За даними опитування громадської організації «Фундація. 101», яка упродовж шести місяців проводила моніторинг ситуації на КПВВ, на першому місці серед причин перетину лінії розмежування - відвідування родичів (до 41 \% опитаних на різних пунктах пропуску). Далі - здійснення покупок (до 38 \%), зняття готівки з банкоматів (до 32 \%), оформлення документів (до $27 \%$ ) [4].

Для жителів населених пунктів уздовж лінії розмежування та непідконтрольних уряду територій (далі - НПУТ) це - «зона видимості» перед органами державної влади, відносна зона безпеки та логістичний вузол для подальшого пересування. Щодня тисячі людей перетинають КПВВ в обох напрямках, несучи з собою тягарі конфлікту та сподівання.

Описати це все можна так: довжелезні черги, недостатня пропускна спроможність, відсутність руху громадського транспорту через лінію розмежування, неналежні умови для тривалого перебування в очікуванні проходження відповідних процедур, зокрема і для осіб з обмеженими фізичними можливостями.

У Луганській області мирні жителі можуть перетнути лінію зіткнення через КПВВ «Станиця Луганська» тільки в пішохідному режимі, через пішохідний міст у Станиці Луганській. У зимовий період, коли температура в Україні опускається нижче нуля, критично важливо поліпшити роботу основних служб контрольно-пропускних пунктів, на яких люди як і раніше змушені чекати по кілька годин, щоб перетнути лінію дотику.
Протягом січня - вересня 2019 р. на пунктах перетину з обох сторін лінії розмежування померло 38 людей [5] та ще 6 осіб - до кінця 2019 р., більшість із цих людей були особами літнього віку. Цього ж року зафіксовано понад 200 випадків госпіталізацій до медичних закладів пацієнтів із КПВВ. Усі ці люди потребували екстреної медичної допомоги. До прибуття карети швидкої допомоги за їхні життя та здоров'я боролися представники різних державних служб (немедичного профілю) та неурядових організацій, які надають першу медичну допомогу на КПВВ. Ці офіційні статистичні дані не включають кількість випадків надання екстреної медичної допомоги силами військових медиків та волонтерів [6].

Медичну допомогу за видами поділяють на екстрену, первинну, вторинну (спеціалізовану), третинну (високоспеціалізовану), паліативну, медичну реабілітацію. Окремо виділяють домедичну допомогу. У контексті нашого дослідження вивчали доступ до домедичної, первинної та екстреної медичної допомоги (ЕМД).

Домедична допомога - невідкладні дії та організаційні заходи, спрямовані на врятування та збереження життя людини у невідкладному стані та мінімізацію наслідків впливу такого стану на її здоров'я, що здійснюються на місці події особами, які не мають медичної освіти, але за своїми службовими обов'язками повинні володіти основними практичними навичками 3 рятування та збереження життя людини, яка перебуває у невідкладному стані, та відповідно до закону зобов'язані здійснювати такі дії та заходи [7]. Також цей вид допомоги називають «долікарською», оскільки її надають особи, які не мають медичної освіти, але володіють базовими прийомами рятування людей в кризових для життя і здоров'я ситуаціях.

Домедична допомога розпочинається зі зобов'язання будь-якої особи, яка виявила людину в невідкладному стані, викликати службу ЕМД або повідомити про виявлену людину в невідкладному стані та про місце події працівникам найближчого закладу охорони здоров'я чи будь-якій особі, яка зобов'язана надавати домедичну допомогу та перебуває поблизу місця події, відповідно до ст. 3 Закону України «Про екстрену медичну допомогу». До комплексу заходів домедичної допомоги входять такі дії, як зупинка кровотечі, накладання пов'язки на рану, штучне дихання, масаж серця (в тому числі зі застосуванням дефібрилятора) та інше, зважаючи на обставини. Міністерство охорони здоров'я розробило і затвердило 29 порядків надання 
домедичної допомоги в ситуаціях: раптової зупинки серця, серцевого нападу, при підозрі на ушкодження хребта, травму голови, інсульт, перелом кінцівок, отруєння, при опіках, переохолодженні/відмороженні, перегріванні, укусах тварин та комах, судомах, втраті свідомості та інших випадках [8]. У нашій ситуації найчастіше траплялися серцеві напади, інсульти, втрата свідомості тощо.

Найпоширенішими причинами смертності в Україні та на КПВВ $є$ захворювання системи кровообігу, зовнішні причини смерті (нещасні випадки, дорожньо-транспортні пригоди, насильницькі дії) та новоутворення. 90,1% смертей серед пацієнтів з ішемічною хворобою серця відбувається поза межами лікарні. 9,9 \% пацієнтів із цим діагнозом помирає у лікарні. Шанси на те, що в разі настання нещасного випадку чи серцевого нападу життя людини буде врятоване, а негативні наслідки для здоров'я - мінімізовані, залежать від строку початку надання допомоги та строку початку проведення критичних для виживання процедур на догоспітальному етапі, які повинні бути мінімальними, а також ефективного госпітального лікування та реабілітації. Кожна з перелічених ланок в Україні організована неефективно [8]. У випадках, пов'язаних із зупинкою серця, домедична допомога включає необхідність проведення серцево-легеневої реанімації, в тому числі зі застосуванням автоматичного зовнішнього дефібрилятора, чого на КПВВ звісно ж немає, як й іншого обладнання.

Первинна медична допомога - медична допомога, що передбачає надання консультації, проведення діагностики та лікування найпоширеніших хвороб, травм, отруєнь, патологічних, фізіологічних (під час вагітності) станів, здійснення профілактичних заходів; направлення відповідно до медичних показань пацієнта, який не потребує екстреної медичної допомоги, для надання йому вторинної (спеціалізованої) або третинної (високоспеціалізованої) медичної допомоги; надання невідкладної медичної допомоги у разі розладу фізичного чи психічного здоров'я пацієнта, який не потребує екстреної, вторинної (спеціалізованої) або третинної (високоспеціалізованої) медичної допомоги [7]. У межах медичної реформи ПМД в Україні таку допомогу безкоштовно можуть отримати лише ті люди, які підписали декларацію зі сімейним лікарем і лише у тих медичних закладах, що співпрацюють із Національною службою здоров'я України (НСЗУ). Обсяг програми медичних гарантій на рівні ПМД визначено у Порядку надання первинної медико-санітарної допомоги, затвердженому наказом Міністерства охорони здоров'я від 19 березня 2018 р. № 504 [10].

Екстрена медична допомога - медична допомога, яка полягає у здійсненні працівниками системи екстреної медичної допомоги невідкладних організаційних, діагностичних та лікувальних заходів, спрямованих на врятування і збереження життя людини у невідкладному стані та мінімізацію наслідків впливу такого стану на їі здоров'я [7]. Невідкладним станом людини вважають раптове погіршення фізичного або психічного здоров'я, яке становить пряму та невідворотну загрозу життю та здоров'ю людини або людей, які її оточують, і виникає внаслідок хвороби, травми, отруєння або інших внутрішніх чи зовнішніх причин [7]. 31 квітня 2020 р. ЕМД надають за новими принципами в межах долучення до чергового етапу реформи галузі медичної допомоги в Україні. Кабінет Міністрів України (КМУ) прийняв розпорядження, яким схвалив Концепцію розвитку системи екстреної медичної допомоги (надалі - Концепція), яка описує основні проблеми галузі та визначає кроки для їх розв'язання [9].

Наразі відсутня стратегія надання медичної допомоги на КПВВ в органів державної влади чи місцевого самоврядування. Проте на КПВВ регулярно надають домедичну, первинну й екстрену медичну допомогу у вимушеному режимі.

У Луганській області на КПВВ «Станиця Луганська» ПМД надають представники Міжнародної медичної допомоги, Товариства Червоного Хреста України (ТЧХУ) в Луганській області та ДСНС. За сукупними даними PUI, Луганської обласної організації ТЧХУ та ДСНС у Луганській області, протягом 2018 р. та дев'яти місяців 2019 р. було надано 38624 консультації в межах домедичної та первинної медичної допомоги (табл. 1).

Попит на медичну допомогу на КПВВ є стабільно високим з початку роботи медичних пунктів. Проте ресурси неурядових організацій, які ії надають, скорочуються, що пов'язано зі зменшенням розмірів донорського фінансування. Оскільки гарантом права на медичну допомогу є держава, тому рано чи пізно державі потрібно буде реально долучитися до процесу забезпечення людей доступом до медичної допомоги на КПВВ.

Також у Станиці Луганській є досвід залучення медичного персоналу місцевого закладу охорони здоров'я до надання медичної допомоги подорожнім 
Табличя 1. Кількість випадків надання медичної допомоги/консультацій протягом січня - вересня 2019 р.

\begin{tabular}{|c|c|c|c|c|c|}
\hline \multirow{2}{*}{ КПВВ } & \multicolumn{2}{|c|}{$\begin{array}{c}\text { Головне управління ДСНС } \\
\text { у Луганській області }\end{array}$} & \multicolumn{2}{|c|}{$\begin{array}{c}\text { Товариство Червоного Хреста } \\
\text { у Луганській області }\end{array}$} & \multirow{2}{*}{ Загалом } \\
\cline { 2 - 5 } & 2018 р. & 9 міс. 2019 р. & 2018 p. & 9 міс. 2019 р. & 38624 \\
\hline $\begin{array}{c}\text { «Станиця } \\
\text { Луганська» }\end{array}$ & 11439 & 9117 & 13351 & 4717 & 3 \\
\hline
\end{tabular}

безпосередньо на КПВВ. Реформа системи ПМД та децентралізація органів місцевого самоврядування нерівномірно торкнулися територій Донецької та Луганської областей, особливо тих, що розташовані поблизу лінії розмежування, в тому числі населених пунктів поблизу КПВВ. Формально, відповідно до розроблених та затверджених Планів спроможної мережі надання первинної медичної допомоги Луганської області [11], кожен із населених пунктів поблизу лінії розмежування повинен мати доступ до пункту надання ПМД, який розташований не більше ніж на відстані семи кілометрів по дорозі з твердим покриттям [12].

Труднощі з доступом до первинної та екстреної медичної допомоги на КПВВ та вздовж лінії розмежування $\epsilon$ наслідками імплементації кардинальних реформ місцевого самоврядування та охорони здоров'я без урахування особливостей територій і громад, де спосіб життя суттєво відрізняється від решти території України.

Наразі органами місцевого самоврядування не прийнято рішення про створення постійного чи тимчасового базування пункту надання ПМД на жодному із КПВВ. У зв'язку із відсутністю визначеної структури, статусу КПВВ та видів діяльності, які можуть там здійснюватися (крім виконання функцій держави), то і фізичні особи-підприємці з ліцензією на право зайняття лікарською діяльністю також не мають можливості долучитися до надання ПМДу межах медичної реформи.

На КПВВ «Станиця Луганська» розташовано 2 пункти медичної допомоги. Графіки роботи організацій мають незначні відмінності, персонал дСНС працює за графіком роботи КПВВ, а інші організації - 3 8:00 до 16:00. 5 медичних працівників та 18 інших спеціалістів (включаючи волонтерів), які допомагають медикам у роботі, долучено до надання первинної медичної допомоги. Медичний пункт допомоги КПВВ «Станиця Луганська» оснащено необхідним переліком медичних та лікарських препаратів, у тому числі дефібрилятором, для надання ПМД хворим [13].

Пункт допомоги на КПВВ «Станиця Луганська» був встановлений за підтримки Міжнародного Комітету Червоного Хреста у грудні 2016 р. по обидві сторони від лінії зіткнення. Крім підтримки комфорту обігріву в зимові місяці та охолодження в літні, в пункті фельдшери-волонтери ще надають і першу медичну допомогу. Але на даний час пункт пропуску «Станиця Луганська» не працює 1 жовтня через лісову пожежу, яка перекинулася на КПВВ. Там згоріла частина гуманітарної інфраструктури пункту пропуску, інші модулі не постраждали [14].

Екстрену медичну допомогу на КПВВ надають станції екстреної (швидкої) медичної допомоги обласних територіальних центрів ЕМД та медицини катастроф, неурядові організації, а також військові швидкі.

Згідно зі статистичними даними, наданими Департаментом охорони здоров'я Луганської, Донецької ВЦА на КПВВ «Станиця Луганська» на Сході України, протягом 2018 р. та дев'яти місяців 2019 р. надано майже в два рази більше ЕМД, ніж на КПВВ Донецької області, що були обрані для порівняння (табл. 2).

Окремої уваги варте питання ефективної діяльності системи зв'язку із диспетчерською службою ЕМД.

Таблиця 2. Надання екстреної медичної допомоги на контрольному пункті в'їзду-виїзду в Луганській та Донецькій областях

\begin{tabular}{|l|c|c|c|c|c|c|}
\hline \multirow{2}{*}{ КПВВ } & \multicolumn{2}{|c|}{ Кількість виїдів карети шМд } & Кількість госпіталізованих осіб & \multicolumn{2}{|c|}{$\begin{array}{c}\text { Кількість летальних } \\
\text { випадків }\end{array}$} \\
\cline { 2 - 7 } & 2018 р. & $\begin{array}{c}\text { січень-вересень } \\
2019 \text { р. }\end{array}$ & 2018 р. & $\begin{array}{c}\text { січень - вересень } \\
2019 \text { р. }\end{array}$ & $\begin{array}{c}\text { січень - } \\
2018 \text { р. } \\
\text { вересень } \\
2019 \text { р. }\end{array}$ \\
\hline «Станиця Луганська» & 365 & 109 & 130 & 83 & 5 & 7 \\
\hline «Майорське» & 84 & 18 & 5 & 0 & 0 & 1 \\
\hline «Мар'інка» & 56 & 46 & 32 & 32 & 2 & 5 \\
\hline «новотроїцьке» & 51 & 26 & 6 & 6 & 1 & 1 \\
\hline «нутове» & 3 & 2 & 2 & 0 & 0 & 0 \\
\hline
\end{tabular}


Коли на КПВВ необхідно викликати «швидку допомогу» з підконтрольної українському уряду території, необхідно знайти і набрати дуже закодований номер, бо якщо телефонувати просто на «101», то дзвінок отримають на окупованій території.

Наявність недоліків у системі центральних оперативних диспетчерських підтверджується також соціально-економічним аналізом Луганської області за 2019 р., підготовленим Луганською ВЦА, в якому йдеться про відсутність централізованої диспетчерської у Луганському обласному центрі ЕМД та медицини катастроф [3], а також даними аналітичних панелей НзСУ [15] щодо обох областей та тезами Концепції розвитку системи ЕМД [9].

Наразі надання ЕМД на КПВВ уздовж лінії розмежування Луганської області забезпечують такі організації та відокремлені підрозділи (табл. 3).

Таблиця 3. Підрозділи та організації, які надають екстрену медичну допомогу на контрольному пункті в'їзду-виїзду вздовж лінії розмежування Луганської області

\begin{tabular}{|c|c|c|c|}
\hline КПВВ & $\begin{array}{c}\text { Служба екстреної медичної } \\
\text { допомоги }\end{array}$ & $\begin{array}{c}\text { Заклад } \\
\text { охорони здоров'я }\end{array}$ & $\begin{array}{c}\text { Відстань від КПВВ } \\
\text { до закладу охорони } \\
\text { здоров'я }\end{array}$ \\
\hline \multirow[t]{2}{*}{$\begin{array}{l}\text { «Станиця } \\
\text { Луганська» }\end{array}$} & $\begin{array}{l}\text { Станично-Луганська підстанція КНП } \\
\text { ЛОР «Луганський регіональний } \\
\text { центр екстреної медичної допомоги } \\
\text { та медицини катастроф» }\end{array}$ & $\begin{array}{l}\text { Комунальне некомерційне } \\
\text { підприємство «Станично- } \\
\text { Луганське районне } \\
\text { територіальне медичне } \\
\text { об'єднання» }\end{array}$ & $3,5 \mathrm{kM}$ \\
\hline & $\begin{array}{l}\text { Підстанція № } 6 \text { м. Щастя КНП ЛОР } \\
\text { «Луганський регіональний центр } \\
\text { екстреної медичної допомоги та } \\
\text { медицини катастроф» }\end{array}$ & $\begin{array}{l}\text { Комунальне некомерційне } \\
\text { підприємство «Щастинська } \\
\text { міська лікарня» Новоайдарської } \\
\text { районної ради Луганської } \\
\text { області }\end{array}$ & $60 \mathrm{kM}$ \\
\hline
\end{tabular}

З 2014 р. із районів, що постраждали внаслідок конфлікту, виїхало понад 1500 спеціалістів сфери охорони здоров'я [16]. Система ЕМД на лінії розмежування також страждає від значного дефіциту персоналу. Зазвичай бригада карети ЕМД складається із трьох осіб: фельдшера, медичної сестри та водія; також $є$ бригади, склад яких підсилений лікарем [17].
У таблиці 4 наведено дані щодо вакантних посад у підстанціях системи ЕМД, які обслуговували КПВВ у Луганській області на кінець листопада 2019 р. Їх аналіз чітко дає зрозуміти про виснаження людських ресурсів системи ЕМД і, як наслідок, неможливість вчасно реагувати на виклики поблизу лінії розмежування та на КПВВ зокрема.

Таблиця 4. Вакантні посади у підстанціях системи екстреної медичної допомоги Луганської області

\begin{tabular}{|l|c|c|}
\hline \multirow{2}{*}{\multicolumn{1}{|c|}{ Посада }} & \multicolumn{2}{|c|}{ КПВВ «Станиця Луганська» } \\
\cline { 2 - 3 } & підстанція Станично-Луганська & підстанція № 6 м. Щастя \\
\hline Кількість штатних бригад ЕМд & 2 & 4 \\
\hline Вакансія лікаря & 2,5 & 3,25 \\
\hline Вакансія фельдшера & 3,5 & 4 \\
\hline Вакансія медичної сестри & 0 & 0 \\
\hline Вакансія водія & 0 & 1,5 \\
\hline
\end{tabular}

Висновки. Війна на Сході України набула тривалого характеру. Наш аналіз показав, що довгострокові наслідки стають усе більше серйозними та поглиблюють дискримінацію в якості життя населення та доступність до базових державних сервісів між територіями, що розташовані поблизу лінії розмежування, та іншими контрольованими Урядом України територіями. У перспективі захворюваність та смертність від хвороб, що не лікували, і травм, викликаних тривалою кризою, ставатимуть на заваді процесам відновлення і розвитку, а також можуть вплинути на життя наступних поколінь.

Лінія зіткнення на Сході України існує вже понад 5 років і продовжує розділяти Донецьку та Луганську області України, що також обмежує свободу пересування населення. Місцевість поблизу неї сильно забруднена мінами, а загальна безпекова ситуація залишається непередбачуваною, що, в свою чергу, 
становить загрозу для цивільного населення при перетині п'яти КПВВ і відповідних блокпостів. Це становище часто погіршується через нестачу належної інфраструктури та медичної допомоги. Системних рішень щодо організації медичних служб для цивільного населення на КПВВ узгоджено не було через низку причин, а саме:

- первинна структура КПВВ формувалася із максимальним наближенням до форми й вигляду контрольних пунктів на кордоні України, які не передбачають наявності пунктів медичної допомоги;

- реформа первинної ланки медичної допомоги та процеси децентралізації не спроможні задовольнити потребу в первинній медичній допомозі на КПВВ.

Для врегулювання питання надання медичної допомоги на КПВВ за рахунок державних коштів (відповідно до ст. 49 Конституції України саме «Держава створює умови для ефективного і доступного для всіх громадян медичного обслуговування») та запобігання смертям у майбутньому потрібно розробити та затвердити відповідні рішення.

\section{СПИСОК ЛІТЕРАТУРИ}

1. План гуманітарного реагування (січень - грудень 2019 р.) [Електронний ресурс] // Представництво оОн з координації гуманітарних питань. - Режим доступу : https://www.humanitarianresponse.info/sites/ www.humanitarianresponse.info/files/documents/files/ ukraine_209_humanitarian_response_plan_ua.pdf.

2. Касумова Р. Люди гинуть за прохід: життя і смерть на лінії розмежування / Р. Касумова // Українська правда. 2017. - 12 вересня.

3. Соціально-економічний аналіз Луганської області, 2019 р. -37 c.

4. Громадська організація «ФУНДАЦІЯ. 101» [Електронний ресурс]. - Режим доступу : https://www. foundation101.org/news/20160913.

5. Спільна заява: Чотири глави держав, Чотири гуманітарні питання [Електронний ресурс]. - Режим доступу : https://www. clovekvtisni.cz/media/publications/1353/ file/1912---n4-ngos-statement_ukr_v1.pdf.

6. Доступ до медичної допомоги на КПВВ: загрози та шляхи розв'язання [Електронний ресурс] // Право на захист. - Режим доступу : https://r2p.org.ua/dostupdo-medychnoyi-dopomogy-na-kpvv-zagrozy-ta-shlyahyrozvyazannya.

7. Основи законодавства України про охорону здоров'я : Закон України від 19 листопада 1992 р. // Відомості Верховної Ради України. - 1993. - № 4. - Ст. 19.
Необхідно звернути увагу на те, що організаційні заходи, які успішно працюють на території інших областей України, на сході країни не працюють, або не можливі до виконання.

Потрібно врегулювати статус КПВВ, уніфікувати перелік послуг та сервісів, які надають на КПВВ (у тому числі питання доступу до медичної допомоги), чітко визначити балансоутримувачів КПВВ та порядок фінансування утримання та забезпечення.

Для зменшення переміщення осіб через КПВВ, необхідно оптимізувати процеси вирішення потреб населення в публічно-адміністративних послугах.

Розробити альтернативний порядок доступу до первинної медичної допомоги на КПВВ коштом державних програм, але поза межами алгоритму, запровадженого медичною реформою: «пацієнт декларація про медичну допомогу - терапевт медичний заклад».

Посилити технічні спроможності та кадровий потенціал мережі станцій екстреної медичної допомоги поблизу КПВВ.

8. Про затвердження порядків надання домедичної допомоги особам при невідкладних станах : наказ Міністерства охорони здоров'я України від 16.06.2014 р. № 398.

9. Про схвалення Концепції розвитку системи екстреної медичної допомоги : розпорядження Кабінету Міністрів України від 22 травня 2019 р. № 383-р.

10. Про затвердження Порядку надання первинної медичної допомоги : наказ Міністерства охорони здоров'я України від 19 березня 2018 р. № 504.

11. Про затвердження плану спроможної мережі надання первинної медичної допомоги Луганської області : розпорядження Луганської обласної державної адміністрації, Луганської обласної військово-цивільної адміністрації від 30 травня 2018 р. № 423.

12. Про затвердження Порядку формування спроможних мереж надання первинної медичної допомоги : наказ Міністерства охорони здоров'я України та Міністерства регіонального розвитку, будівництва та житлово-комунального господарства України від 6 лютого 2018 р. № 178/24.

13. Дослідження умов доступу до медичної допомоги на КПВВ : моніторинговий звіт [Електронний ресурс] // Право на захист. - Режим доступу : https://r2p.org.ua/ monitoryngovyj-zvit-doslidzhennya-umov-dostupu-domedychnoyi-dopomogy-na-kpvv/. 
14. Червоний Хрест відновить знищений вогнем модуль на КПВВ «Станиця Луганська» [Електронний ресурс] // Новинарня. - Режим доступу : https://novynarnia. com/2020/10/02/chervonyj-khrest-vidnovyt/.

15. Аналітична панель Національної служби здоров'я України.

16. Огляд гуманітарних потреб 2019 р. // Представництво ООН з координації гуманітарних питань
[Електронний ресурс]. - Режим доступу : https:// www. humanitarianresponse.info/sites/www. humanitarianresponse.info/files/documents/files/ukraine_ 2019_humanitarian_needs_overview_ua.pdf.

17. Про затвердження Типового положення про бригаду екстреної (швидкої) медичної допомоги : Постанова Кабінету Міністрів України від 21 листопада 2012 р. № 1114.

Отримано 19.11.20 